\title{
Properties of modified concrete with crumb rubber: Effect of the incorporation of hollow glass microspheres
}

\author{
Propiedades de concreto modificado con llantas trituradas: Efecto de la incorporación de \\ microesferas de vidrio
}

\author{
Juan Pablo Valencia-Villegas (D) ${ }^{1}$, Ana María González-Mesa (D) ${ }^{1}$, Oscar Felipe Arbeláez-Pérez (D) 1* \\ ${ }^{1}$ TERMOMEC, Facultad de Ingeniería, Universidad Cooperativa de Colombia. C.P.050016. Calle 50 \# 41 - 74 - Bloque A - Piso 4. Medellín, \\ Colombia.
}

\section{CITE THIS ARTICLE AS:}

J. P. Valencia, A. M. González and O. F. Arbeláez. "Properties of modified concrete with crumb rubber: Effect of the incorporation of hollow glass microspheres", Revista Facultad de Ingeniería Universidad de Antioquia, no. 98, pp. 59-68, Jan-Mar 2021. [Online]. Available: https: //www.doi.org/10.17533/ udea.redin. 20200473

\section{ARTICLE INFO:}

Received: October 10, 2019 Accepted: March 28, 2020

Available online: April 28, 2020

\section{KEYWORDS:}

Modified concrete; hollow glass microspheres; crumb rubber; synergetic effect

Concreto modificado; microesferas de vidrio; residuos de llantas; efecto sinérgico
ABSTRACT: In this study, the effect of incorporating hollow glass microspheres (HGM) on the mechanical properties of modified concrete with CR (crumb rubber) was evaluated. Different concrete samples replacing $15 \%$ of fine aggregates (total weight of CR + HGM $=15 \%$ l were prepared. It was found that the increase in the microsphere content was directly proportional to the slump, compressive strength, and the modulus of elasticity. The increase in the microsphere content was inversely proportional to density. Additionally, we found that in the modified concrete, the width, height and the number of cracks increased as the HGM content increases. The combined sample HGM12.5-CR2.5 (the one with the highest content of microspheres) resulted in concrete with the highest compressive strength of $19.1 \mathrm{MPa}$, which is $243 \%$ stronger than the concrete with only crumb rubber (9.2 MPa). From the XRD results, we were able to detect the presence of different phases formed by hydration during the process of preparing concrete mixtures. The micrographs allowed identifying the fracture in the microspheres during the preparation of the concrete mixtures when they came into contact with the aggregates. The addition of hollow glass microspheres to the mixtures prepared from crumb rubber improved their mechanical properties, and this makes it a potential system that can replace the traditional materials in the production of concrete.

RESUMEN: En este estudio se evaluó el efecto de la incorporación de microesferas de vidrio en las propiedades mecánicas de concretos modificados con residuos de llantas (CR). Se prepararon especímenes cilíndricos con reemplazos del $15 \%$ de los agreados finos (peso total = peso $\mathrm{HGM}+$ peso $\mathrm{CR}$ ). Se encontró que un incremento en el contenido de microesferas fue directamente proporcional al asentamiento, la resistencia a la compresión y al modulo de elasticidad. El incremento en el contenido de microesferas fue inversamente proporcional a la densidad. Adicionalmente, se encontró que en los concretos modificados, el ancho, la altura y el numero de grietas aumenta con el aumento en el contenido de microesferas. La mezcla combinada HGM12,5-CR2,5 (la de mayor contenido de microesferas) resultó ser la de mayor resistencia a la compresión, 19,1 MPa, la cual presenta un aumento del $243 \%$ con respecto a la muestra preparada solo con llantas trituradas 9,2 MPa. Los resultados de DRX permitieron identificar la presencia de fases cristalinas formadas en las mezclas con adición de microesferas. Adicionalmente, las micrografías permitieron identificar fracturas en las microesferas, durante la preparación de las mezclas de concreto, al entrar en contacto con los agregados. La adición de microesferas a las mezclas preparadas a partir de llantas trituradas mejora las propiedades mecánicas y se convierte en un sistema potencial como reemplazo de los materiales tradicionales en la elaboración de concreto.

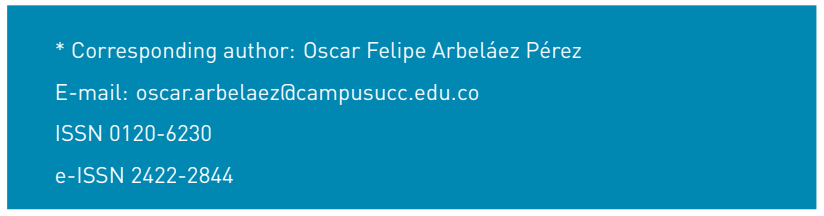

\section{Introduction}

Population growth, urbanization of the cities, continuous industrial development, infrastructure construction, and 
residential construction activities have all increased the requirements for new infrastructure in the construction industry. These requirements demand a greater quantity of raw materials; especially those related to concrete production (water, cement, and fine and coarse aggregates), fine and coarse aggregates are extracted natural resources [1]. Unfortunately, the exploitation of these materials generates a negative environmental impact. It is necessary to generate new policies that limit the exploitation of natural resources, as well as the development of strategies in the search for new materials, especially those that allow the use of waste material, which then can be used in the construction industry. Various studies focused on the preparation of modified mortars and concretes using fly ash [2], demolition waste [3], recycle aggregated [4, 5], nanomaterial [6], rice hush [7], silica mineral [8], ceramic waste [9, 10], fly ash combined with glass fiber [11], among others as partial replacement for cement, fine and coarse aggregates. Incorporating other materials in building materials affect their mechanical and physical properties [12]. Replacing fine aggregate with $10 \%, 20 \%$, and $30 \%$ by volume recycled tire aggregates [13]. The particle size of the fine aggregate is in the range of 4.75 to $0.15 \mathrm{~mm}$. They also replaced the coarse aggregates with recycled tire crumb rubber (CR) wastes with particle sizes in the range of 12.5 to $9.5 \mathrm{~mm}$. As a result of this replacement, they observed a decrease in the compressive strength, directly proportional to the increase of recycled tire waste content. These results are more significant when the recycled tire waste is used to replace the coarse aggregates. In fact, it was reported that a $30 \%$ replacement of the coarse aggregates generates a decrease (at day 28) of $74 \%$ in the compressive strength with respect to the traditional concrete. Replacing the coarse aggregates with recycled tire waste modifies the compressive strength $[14,15]$; in fact, the replacement percentages should be less than $25 \%$ and $10 \%$, respectively, for structural concrete. Glass microspheres have also been favorably evaluated as a replacement for cementitious material and aggregates, because of their ability to increase the compressive strength and the density of concrete samples. The effect of replacing $3 \%, 6 \%$, and $9 \%$ of the cement content by glass microspheres in the preparation of lightweight cellular concrete was evaluated [16]. The authors found that the incorporation of $3 \%$ glass microspheres in cement is the most adequate proportion of microspheres that is required to produce concrete suitable for structural applications; in fact, this content of microspheres results in a $22 \%$ increase in the compressive strength. Likewise, a comparative study of the mechanical properties of lightweight cementitious compounds was carried out by replacing $7 \%, 14 \%, 21 \%$, and $28 \%$ by volume of the fine aggregates with microspheres of different sizes [17]. The density of the modified materials decreases as the concentration of microspheres increases, causing reductions in density of up to $2.4 \%, 12 \%, 22.1 \%$, and $31.9 \%$ respectively. In addition, the authors report that, at the age of 28 days, an increase in the compressive strength is attained when the replacement is less than $15 \%$. Additionally, the authors also report that the compressive strength of lightweight concrete is much greater when smaller microspheres are used. Some reports had been conducted a study on the use of glass microspheres with densities of $150 \mathrm{Kg} / \mathrm{m}^{3}$ and 380 $\mathrm{Kg} / \mathrm{m}^{3}$ when manufacturing lightweight concrete with replacements of $10 \%, 20 \%$, and $30 \%$ mass of the fine aggregates. After 28 days, the modulus of elasticity for replacement of $30 \%$ decreased by $91.6 \%$ and $82.6 \%$ with respect to the microspheres of $150 \mathrm{Kg} / \mathrm{m}^{3}$ and $380 \mathrm{Kg} / \mathrm{m}^{3}$ [18]. The authors concluded that the large reduction in the modulus of elasticity is due to the low density of the microspheres; therefore, high percentages of replacement of low-density microspheres produce concrete with a low Young's modulus. The results reported so far show the versatility of the microspheres to increase the compressive strength, decrease the modulus of elasticity of concrete, and the recycled tire waste to lowered the density of modified concrete. In the present research, we focus on the design, preparation and evaluation of the physical and mechanical properties of concrete when replacements of $15 \%$ (hollow glass microspheres $(\mathrm{HGM})+\mathrm{CR}=15 \%$ ) by mass of fine aggregates are applied. The prepared specimens were subjected to a series of tests including density and compressive strength. The effect of HGM and the CR content on the textural and crystalline structure were also investigated.

\section{Experimental methods}

\subsection{Materials}

The constituent materials used for preparing the concrete in this study include Portland cement with a specific density of $3,050 \mathrm{Kg} / \mathrm{m}^{3}$ according to NTC 221 (Colombian Technical Standard) and tap water. Experiments were done to determine the unit compact mass NTC 92 [19], bulk density of fine aggregate NTC 196 [20], bulk density of the coarse aggregate NTC 237 [21], as well as the particle size distribution NTC 77 [22]. HGM (HGM) (particle size of 200 microns and density of $2,400 \mathrm{Kg} / \mathrm{m}^{3}$ ) were provided by FABCOM SAS. CR was supplied by the company $4 \mathrm{R}$ Soluciones Ambientales SAS, the density of the material was $1,109 \mathrm{Kg} / \mathrm{m}^{3}$. A water/cement ratio of 0.58 was used for all mixture. The main properties of the fine and coarse aggregates are summarized in Table 1. 
Table 1 Properties of fine and coarse aggregates

\begin{tabular}{llllll}
\hline Material & $\begin{array}{l}\text { Apparent } \\
\text { density }\end{array}$ & $\begin{array}{l}\text { Fineness } \\
\text { module }\end{array}$ & $\begin{array}{l}\text { Water } \\
\text { adsorption (\%) }\end{array}$ & $\begin{array}{l}\text { Unit mass } \\
\text { compact }\end{array}$ & $\begin{array}{l}\text { Maximum nominal } \\
\text { size }\end{array}$ \\
\hline fine aggregate & 2,710 & 3.17 & 0.9 & 1,740 & 4.75 \\
coarse aggregate & 2,710 & - & 0.7 & 1,574 & 25.0 \\
\hline
\end{tabular}

Table 2 Mix proportions of prepared sample

\begin{tabular}{llllll}
\hline Mixture* & $\begin{array}{l}\text { Fine } \\
\text { aggregate }\end{array}$ & $\begin{array}{l}\text { Coarse } \\
\text { aggregate }\end{array}$ & $\begin{array}{l}\text { Hollow glass } \\
\text { microspheres }\end{array}$ & $\begin{array}{l}\text { Crumb } \\
\text { rubber }\end{array}$ & $\begin{array}{l}\text { Weight } \\
\text { HGM/Weight } \\
\text { total (\%) }\end{array}$ \\
\hline HGM0-CR0 & 765 & 1,034 & 0 & 0 & 0 \\
HGM0-CR15 & 644 & 1,032 & 0 & 112 & 0 \\
HGM2.5-CR12.5 & 643 & 1,035 & 28 & 84 & 1.64 \\
HGM7.5-CR7.5 & 644 & 1,032 & 56 & 56 & 3.23 \\
HGM12.5-CR2.5 & 643 & 1,035 & 84 & 28 & 4.77 \\
HGM15-CR0 & 644 & 1,032 & 112 & 0 & 6.26 \\
\hline * All units are in kilograms per cubic meter for the prepared concrete. The total weight included \\
the mass of CR, HGM, fine and coarse aggregate.
\end{tabular}

\subsection{Mixture design}

Concrete mix design was carried out using the $\mathrm{ACl} 211.18$ (American Concrete Institute) method [23], A total of 6 mixtures were produced, a reference mixture (traditional concrete) and 5 mixtures were prepared with a 15\% (HGM $+\mathrm{CR}=15 \%$ ) mass replacement of the fine aggregate. The mixtures were labeled as HGM-CR, where HGM and $\mathrm{CR}$ denote the percentages of the HGM and the $\mathrm{CR}$ replacement, respectively. For instance, HM3.75WR11.25 represents a concrete mix with a replacement by $3.75 \%$ of hollow microspheres and $11.25 \%$ by CR. The quantities of each material are shown in Table 2.

\subsection{Preparation of concrete mixtures}

For the preparation of the mixtures, the coarse aggregate was moistened to reach Saturated Surface Dry (SSD) condition. Before mixing begins, the interior of the mixer is moistened. First, the coarse aggregate, the sand, and the $\mathrm{CR}$ were mixed until a homogeneous mixture was attained. The cement and $75 \%$ of the water were then added and mixed for 4 minutes. When a cohesive and fluid paste was observed, the HGM (in the case of mixtures with HGM) and the remaining $25 \%$ of water were added. The slump test was used according to the requirements of NTC 396 to analyze the properties of fresh concrete [24]. The mold was filled in three layers of fresh concrete mixture, each approximately one-third of the height of mold and compacted. Each layer was compacted with a tamping rod 25 times. After the top layer was compacted, the surface was struck off with the compacting rod. Immediately after slump cone was lifted, the slump was measured by determining the difference between the height of the mold and that of the highest point of the slumped test mixture.

\subsection{Preparation of the concrete specimens}

A total of 12 cylindrical specimens of $150 \mathrm{~mm}$ in diameter and $300 \mathrm{~mm}$ in length were prepared according to NTC 550 methodology [25]. Before preparing the specimens, the inner surface of the molds was covered with a thin layer of mineral oil to prevent concrete from sticking to the mold. All the concrete molds were filled in three equal layers, each compacted with 25 strokes distributed across the surface using a $16 \mathrm{~mm}$ diameter rod. Subsequently, the mold was struck 15 times with a rubber hammer in order to remove the air bubbles from each layer. The last layer was flushed with a rod. The surface of the molds was covered with polyethylene sheets to maintain the moisture of the specimens. After 24 hours, the cylinder mold was removed and placed in saturated water with calcium oxide at room temperature for 28 days according to NTC 550 .

\subsection{Performance evaluation}

The hardened concrete density was evaluated at the age of 28 days according to ASTM C1754. Compressive strength tests were carried out on an electro-hydraulic servo-controlled machine with a 1,500 kN capacity. An axial load was applied to the cylinders at a constant load ratio of $0.6 \mathrm{MPa} / \mathrm{s}$. The density $(\rho)$ and module of elasticity $\left(E_{c}\right)$ were evaluated using Equations 1 and 2, respectively.

$$
\begin{gathered}
\rho=\frac{M}{V} \\
E_{c}=W_{c}^{1.5} 0.034 \sqrt{f_{c}^{\prime}}
\end{gathered}
$$

Where $\rho$ is the density in $\mathrm{Kg} / \mathrm{m}^{3}, M$ is the sample mass in $\mathrm{Kg}, V$ is the volume in $\mathrm{m}^{3}, E_{c}$ is the elasticity modulus in 
$\mathrm{MPa}, W_{c}$ is the apparent density of the hardened concrete in $\mathrm{Kg} / \mathrm{m}^{3}$, and $f_{c}^{\prime}$ is compressive strength in MPa.

\subsection{Characterization of the prepared samples}

The crystallinity of concrete samples was determined by X-Ray Diffraction on a Phillips PW 1,740 diffractometer using $\mathrm{Cu} \mathrm{K} \alpha$ radiation and $\mathrm{Ni}$ filter operated at $40 \mathrm{kV}$ and $20 \mathrm{~mA}$. The $2 \theta$ scanning range was $5^{\circ}-70^{\circ}$ at $2 \%$ min. The diffractograms were compared with the JCPDS (Joint Committee of Powder Diffraction Standards database). The morphology and microstructure of the samples was recorded using a JEOL JSM 6,490 LV equipped with an energy dispersive X-ray spectroscopy analyzer NCA PentaFETx3 Oxford instrument operated at $200 \mathrm{kV}$ and 124 $\mu \mathrm{A}$. The samples were covered with Au before the analysis using an equipment DENTON VACUUM Desk IV.

\section{Results and discussions}

The workability of fresh pervious concrete mixes was characterized by the slump. Table 3 shows the slump, slump reduction, and density of the prepared samples.

Table 3 indicates that a slump value between 80 and $200 \mathrm{~mm}$ can be achieved by varying the percentage HGM and $C R$ while the coarse aggregate and cement are fixed. From the experimental results, the HGM or CRaddition increases the slump in comparison with the traditional concrete. HGM15-CRO and HGM2.5-CR12.5 samples exhibited the highest and lowest slump, respectively. This reduction is mainly due to the change in particle shape and nature when fine coarse was replaced by hollow glass and CR. In the prepared mixes with HGM and CR, the addition of $\mathrm{HGM}$ resulted in a combined effect between the CR tire and hollow microspheres. In fact, sample HGM7.5-CR7.5 exhibited the highest slump, and this is due to the combined effect between the HGM and CR. The increased slump (108\%) in concrete is related to the spherical shape which allowed for a much easier displacement of aggregates within the paste, besides the surface of the microspheres is soft, which implies a lower force of friction between the particles. Additionally, the non-polarity of the CR traps air into the mixture [26], therefore, increasing the fluidity of the mixture. From the information in Table 3 , a reduction in the concrete density was observed with the incorporation of $\mathrm{HGM}$ and $\mathrm{CR}$; this was mainly due to the differences in the density of the $\operatorname{HGM}\left(2,400 \mathrm{Kg} / \mathrm{m}^{3}\right)$ and $\operatorname{CR}\left(1,109 \mathrm{Kg} / \mathrm{m}^{3}\right)$ in comparison with the fine and coarse aggregates. In Table 3 , it can be seen that as the CR concentration increases, the density of the samples gradually decreases. The density results of HGM15-CR0, HGM12.5-CR2.5, HGM7.5-CR7.5, HGM2.5-CR12.5, and
HGM0-CR15 samples were 0.92\%, 2.40\%, 3.32\%, 5.40\%, and $9.08 \%$ respectively, as compared to the reference sample. This is in agreement with the original density values of the materials, where $\mathrm{CR}$ possesses a relatively lower density $\left(1,109 \mathrm{Kg} / \mathrm{m}^{3}\right)$ than $\operatorname{HGM}\left(2,400 \mathrm{Kg} / \mathrm{m}^{3}\right)$, fine $\left(2,710 \mathrm{~kg} / \mathrm{m}^{3}\right)$, and coarse $\left(2,710 \mathrm{~kg} / \mathrm{m}^{3}\right)$ aggregates. This behavior was previously reported by [26] who suggested that the non-polar nature of rubber particles may be the reason for its ability to repel water and entrap air on the rubber surface, consequently increasing the number of air voids, and thus decreasing the concrete density.

The failure modes of the cylinder specimens under axial compression are shown in Figure 1.

From Figure 1, it can be seen that the largest macrocrack is present in the specimen of mixture HGMO-CRO, which crosses the entire height of the cylinder. Similarly, the HGM15-CRO mixture has macrocracks, but these do not completely cross the height of the cylinder. On the other hand, the cylinders of the HGM0-CR15, HGM7.5-CR7.5, HGM2.5-CR12.5, and CR2.5HGM12.5 mixtures which have a replacement of rubber, small cracks are observed in their surface, however, the definite trend of failure in the specimens is not detailed. This phenomenon can be explained by the low elasticity modulus of the cylinders that is mainly due to the addition of rubber, this is because this material has a very low Young's modulus that enhances the capacity of deformation before cracking, and it also resists further propagation and coalescence of microcracks by decreasing the stress concentration similar to a damper, in agreement with [27]. This is how rubber replacement improves the deformation capacity of concrete before failure as well as mitigating the propagation and bonding of microcracks. Therefore, the width, height, and the number of cracks decrease as the percentage of rubber in the mixture increases, thus presenting a ductile fault. On the contrary, we observe that the specimen of the HGM15-CRO mixture has a brittle fault very similar to the cylinder of the reference mixture. This similarity can be attributed to very similar values of the modulus of elasticity between the HGM and fine and coarse aggregates. Additionally, the HGM used have a higher density than rubber particles, therefore concrete with percentages of high addiction of this type of HGM will present brittle faults such as conventional concrete. It is observed, the addition of CR in prepared samples resulted in a positive synergetic effect with HGM.

The compressive strength results are presented in Figure 2. According to experimental results, the compression strength of the mix prepared with $\mathrm{CR}$ and HGM specimens decreased and a full replacement of $15 \%$ fine aggregates by $\mathrm{CR}$ resulted in a decrease of $63 \%$ in the cylinders compression strength. 
Table 3 Slump and slump reduction, and density of mixed prepared

\begin{tabular}{lllll}
\hline Mixture & Slump (mm) & Slum increasing (\%) & Density $\mathbf{( K g / \mathbf { m } ^ { 3 } )}$ & Density reduction (\%) \\
\hline HGM0-CR0 & 72 & - & 2,499 & - \\
HGM0-CR15 & 90 & 25.5 & 2,272 & 9.08 \\
HGM2.5-CR12.5 & 80 & 11.1 & 2,364 & 5.40 \\
HGM7.5-CR7.5 & 150 & 108 & 2,416 & 3.32 \\
HGM12.5-CR2.5 & 130 & 80.5 & 2,439 & 2.40 \\
HGM15-CR0 & 200 & 177 & 2,476 & 0.92 \\
\hline
\end{tabular}

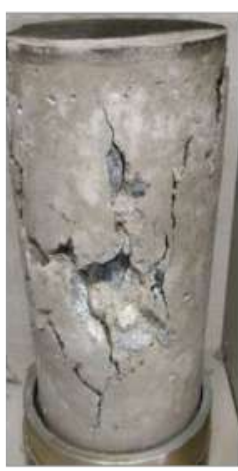

HGM0-CR0

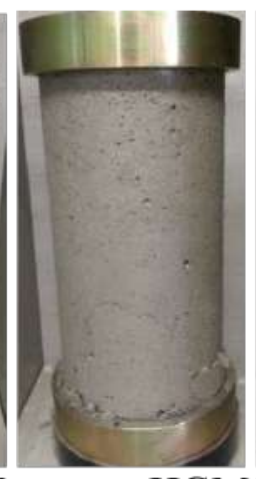

\section{H}

\section{CR12.5 CR2.5HGM12.5}

Figure 1 Modes of failure

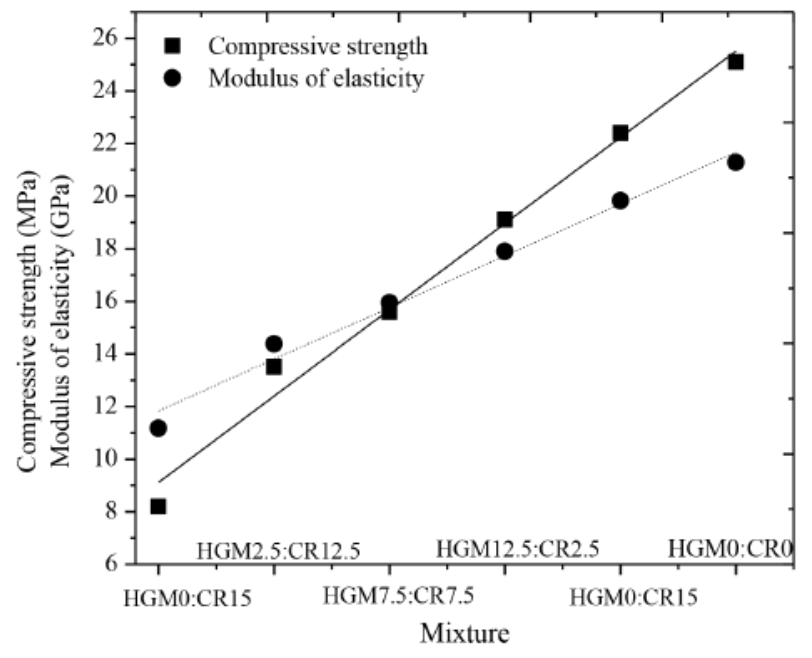

Figure 2 Compressive Strength of prepared samples

The results in Figure 2 show that compressive strength is lower for concrete prepared only with CR, an effect that is associated with the lower Young's modulus lelastomers $0.001-0.02 \mathrm{GPa}$ ) of this material when compared with the fine aggregates, which generates a lower load capacity of the prepared mixtures. Besides, the adherence of the chemical structure of the tire waste (organic nature) to the components of the concrete matrix (inorganic nature) is weak. This is in agreement with previous reports where the surface texture and the chemical structure of polymers result in lower adherence of the polymer particles, the aggregates, and the cement matrix, thereby decreasing the compressive strength of the concrete. From Figure 2, for the concrete mix that has only microspheres HGM15-CR0, a resistance of $22.4 \mathrm{MPa}$ was recorded, which meets the required standard of resistance for structural purposes. For specimens of concrete that have microspheres and tire residues, the compressive strength increases with the increase of the HGM. In fact, the sample HGM12.5-CR2.5 showed the best behavior, with a resistance of $91 \%$ of the actual resistance expected for concrete for structural purposes (21 $\mathrm{MPa}$ ). The results obtained allowed us to conclude that the HGM generates a positive synergic effect on the resistance to compression. This effect is associated with the spherical shape of the microspheres, which fills the voids, decreasing the air content and producing new components in the concrete matrix by a chemical reaction between them and the cement [28].

The results in Figure 2 show that the elasticity modulus is directly proportional to the increase in HGM content. This behavior is related to the elasticity modulus of the concrete and it can be justified by a well-established fact that the modulus of elasticity of concrete depends on the modulus of elasticity of the aggregates and on their volumetric proportion in the matrix. Therefore, aggregates with a high modulus of elasticity generate concrete with a higher modulus. From Figure 2, it can be seen that as the content of HGM increases, the modulus increase. This is 


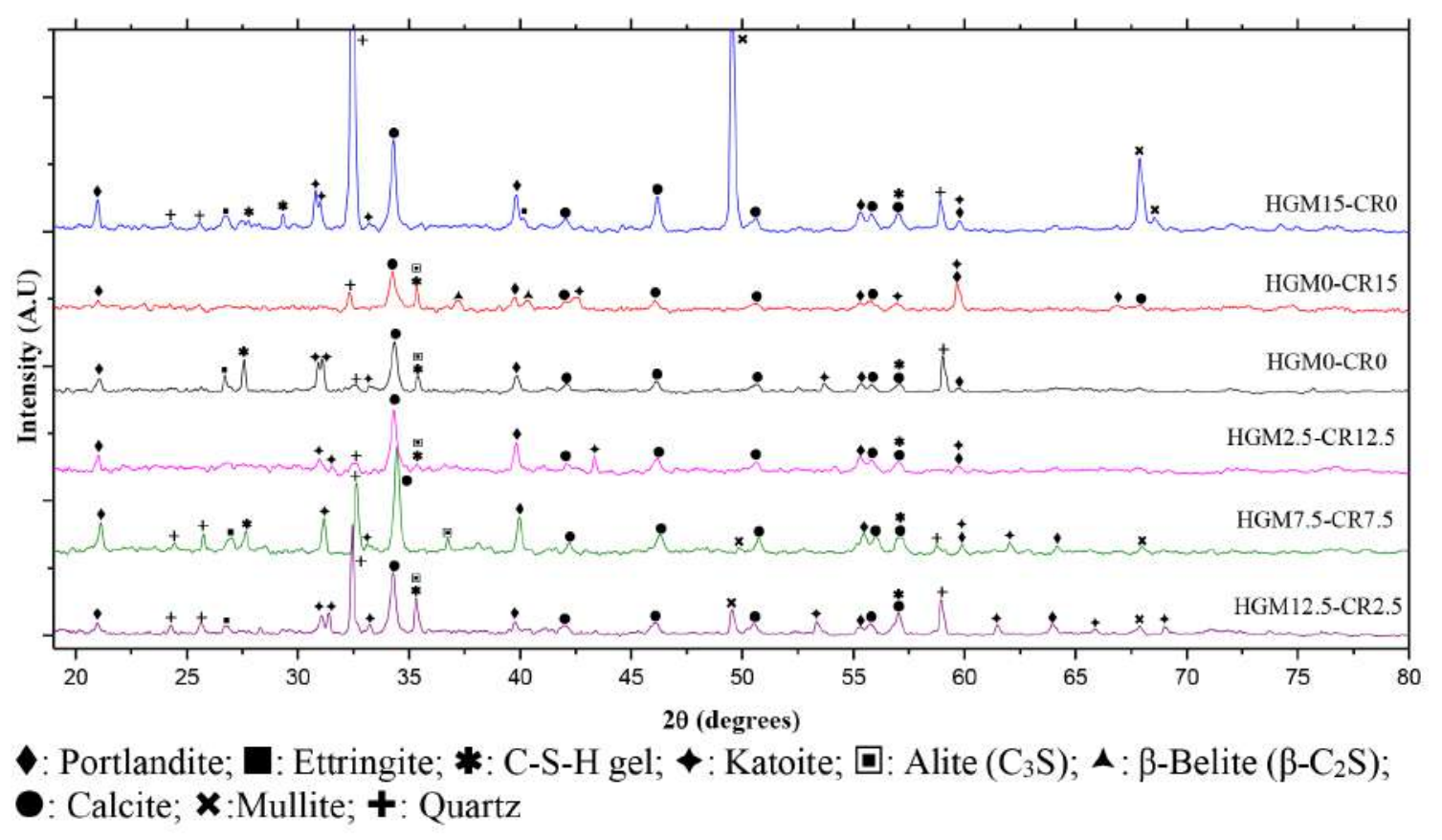

Figure 3 XRD patterns of prepared mixes

observation is in agreement with the compressive strength and the density results presented in Table 3.

The XRD patterns of all mixtures prepared at 28 days of curing are presented in Figure 3. From the analysis of the $X R D$ results, the major phase contribution is centered around $2 \theta=30^{\circ}$. In all mixtures, the three characteristic reflections of portlandite can be observed in the angular position $2 \theta=21.02^{\circ}, 39.81^{\circ}$, and $55.35^{\circ}$ [29], other lower-intensity reflections can also be present. It can be seen that the intensity of the peaks related to portlandite increases when the concentration of HGM is higher. The increase in intensity is possibly due to the $\mathrm{CaO}$ and $\mathrm{SiO}_{2}$ molecules released when the HGM is destroyed during the chemical reactions that occur in the hydration of cement, and thus producing more molecules of $\mathrm{Ca}(\mathrm{OH})_{2}$ during the hydration of $\mathrm{C}_{2} \mathrm{~S}$ (dicalcium silicate) and $\mathrm{C}_{3} \mathrm{~S}$ (tricalcium silicate) [30].

Furthermore, the characteristic peaks of calcite at the angular position $2 \theta=34.40^{\circ}$ can be seen in the XRD results of all mixtures [31]. The intensity of this characteristic peak and other low-intensity peaks increase as the percentage of HGM increases. The increase in calcite intensity is related to the increase of portlandite molecules. Inasmuch as calcite is produced from the chemical reaction of carbonation, in which portlandite reacts with carbon dioxide so that when there is a greater quantity of calcium hydroxide molecules, then high precipitation of $\mathrm{CaCO}_{3}$ is expected. Ettringite formation was not identified for mixtures HGM0-CR15 and HGM2.5-CR12.5, but it was evident for mixtures with

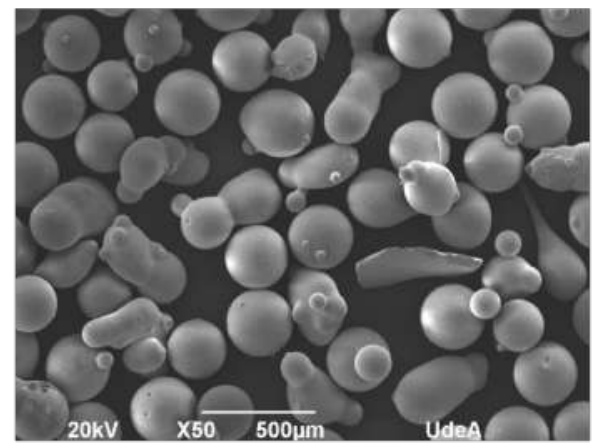

Figure 4 SEM hollow glass microspheres

a higher proportion of HGM, and this is because of the preferential reaction of the aluminates provided by this material. $\quad \mathrm{C}_{3} \mathrm{~S}$ was identified in all samples and $\beta-\mathrm{C}_{2} \mathrm{~S}$ was identified in the HGMO-CR15 mixture as well. This indicates that the incomplete reaction of the main cement phases, at least up to 28 days of curing occurred. It should be noted that the peaks representing the formation of C-S-H (I) tend to show a higher intensity as the percentage of HGM increases. During the hydration process, silicic acid was formed on the surface of the HGM [28] therefore causing a pozzolanic reaction, in which the silicic acid gel reacts with calcium hydroxide and produces more hydrated calcium silicate molecules. Finally, mixtures with a larger portion of HGM tend to produce more peaks and greater intensity of katoite due to the greater magnitude of aluminate that can be obtained through the $\mathrm{HGM}$, therefore it favors the precipitation of this C-A-S-H 


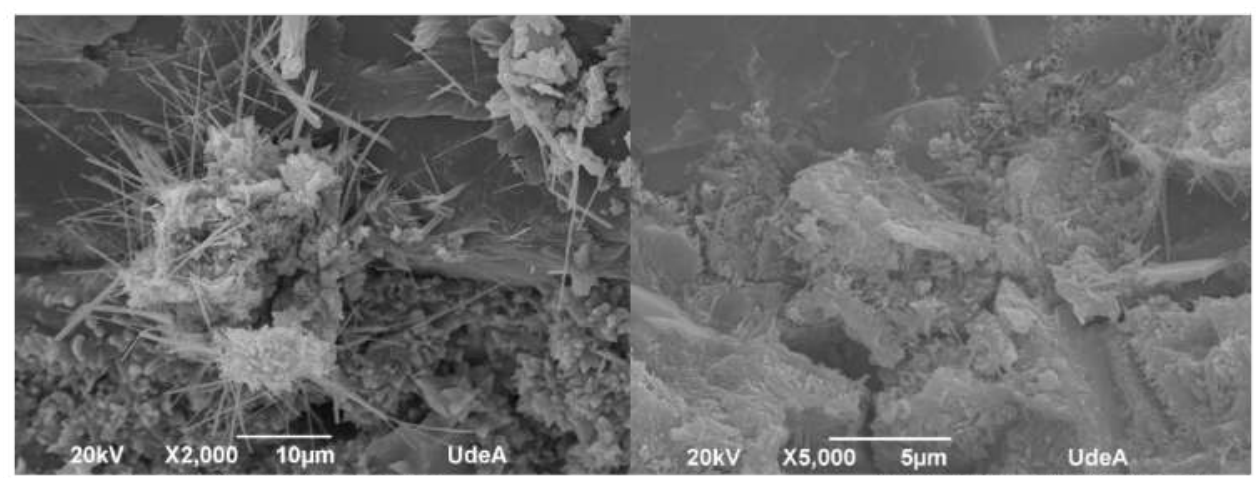

(a) HGM0-CR0 2000X

(b) HGM0-CR15 5000X

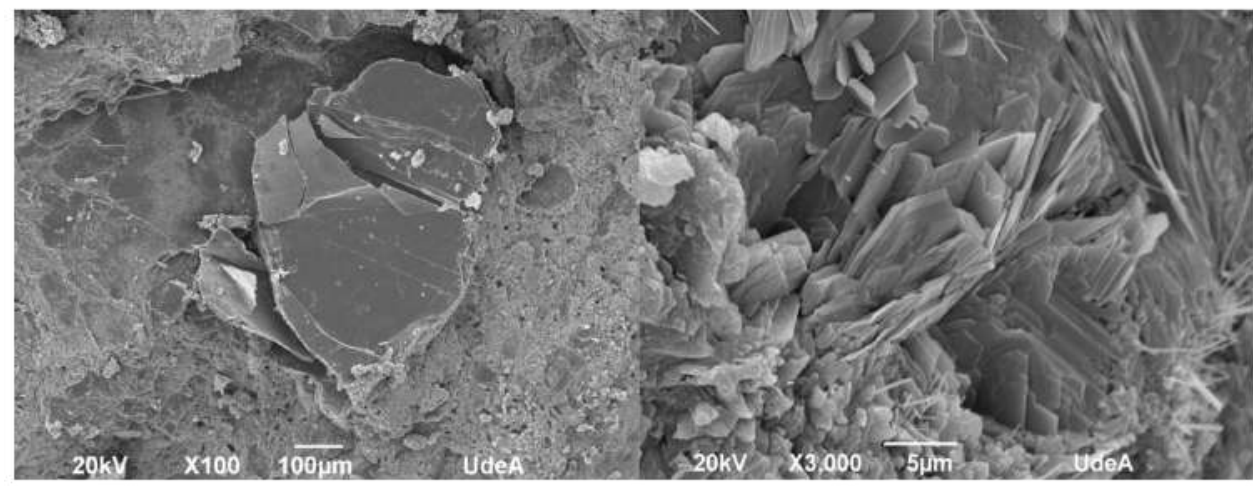

(c) HGM15-CR0 10X

(d) HGM15-CR0 3000X

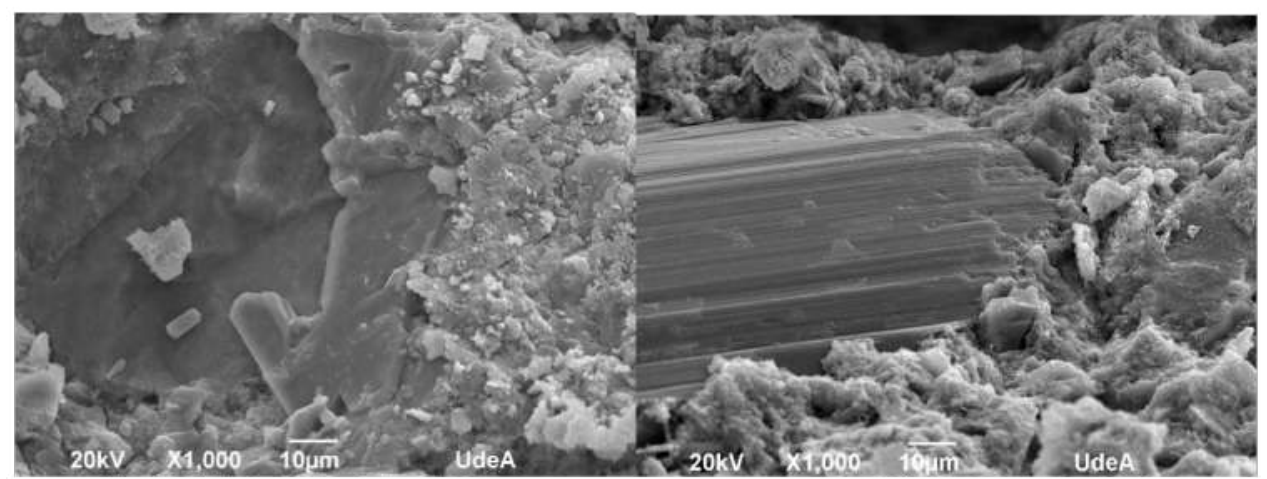

(e) HGM12.5-CR0 1000X

(f) HGM12.5-CR0 1000X

Figure 5 SEM micrographs: (a) HGM0-CR0 2000X, (b) HGM0-CR15 5000X, (c) HGM15-CR0 10X, (d) HGM15-CR0 3000X, (e) HGM12.5-CRO 1000X, (f) HGM12.5-CR0 1000X

(calcium aluminium silicate hydrate). Figure 4 shows the SEM image of HGM. The results of Figure 4 show a smooth clean surface, a perfectly spherical shape with an aspect ratio of one that makes glass bubbles efficient volume fillers. The average size of microspheres was $288.14 \mu \mathrm{m}$ which is similar to the reported size $(300 \mu \mathrm{m})$.

The micrographs of the surfaces of HGMO-CRO, HGM0-CR15, HGM15-CR0, and HGM12.5-CR2.5 are presented in Figure 5.
From HGM0-CR1,5 it can be seen that there are some dents and jagged areas on the surface of the sample, the larger surface area of the finer particles produces more frictional resistance to the flowing movement of fresh concrete. HGM15-CR0 shows the microstructure with microspheres, uniformly distributed throughout the entire volume, and the cement matrix consisting of calcium hydrosilicates. The contact zone "cement stone microsphere" consists of well-formed portlandite clusters and crystal well-identified $\mathrm{Ca}(\mathrm{OH})_{2}$ in the form of dense pyramids that were filling pores as shown, decreasing the porosity of the samples which confirms that this mineral 


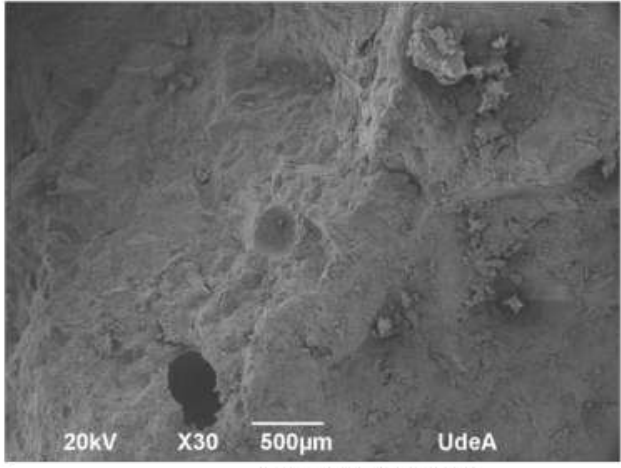

(a) HGM0-CR0

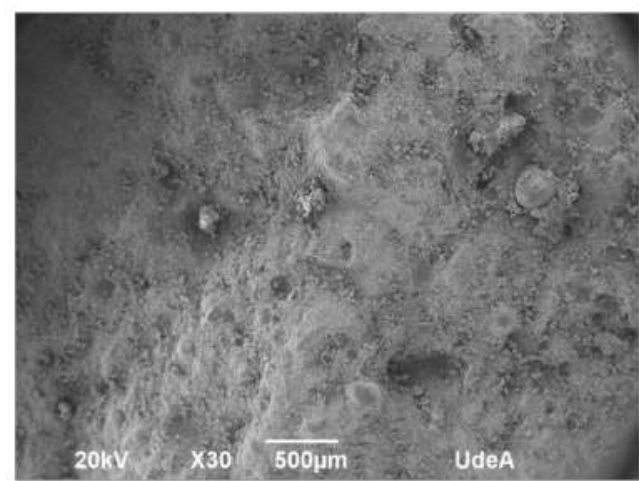

(c) HGM15-CR0

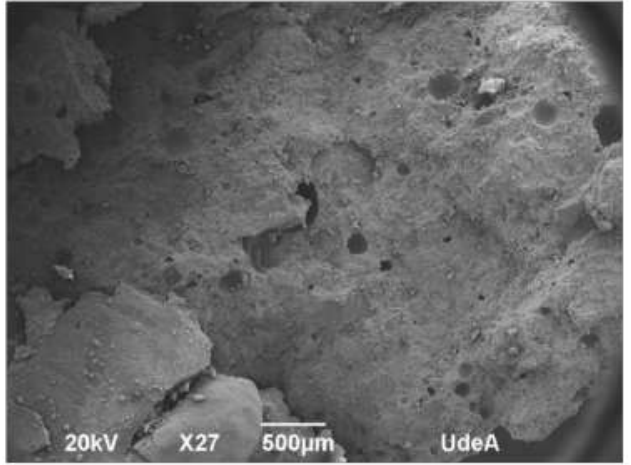

(b) HGM0-CR 15

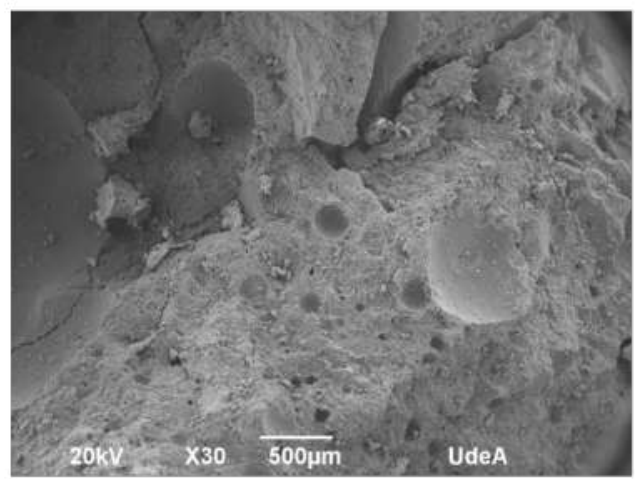

(d) HGM12.5-CR2.5

Figure 6 SEM micrographs X30 from (a) HGM0-CRO, (b) HGM0-CR15, (c) HGM15-CRO, (d) HGM12.5-CR2.5

turns into a more crystallized form during wet curing. Additionally, it can be seen that the microspheres were destroyed, probably by the mixing process with coarse aggregates.

The micrographs of the surface porosity of HGMO-CRO, HGM0-CR15, HGM15-CRO, and HGM12.5-CR2.5 are presented in Figure 6.

From Figure 6, samples HGMO-CR15 and HGM12.5-CR2.5 have a larger number of pores compared to samples HGMO-CRO and HGM15-CRO, which do not contain CR. Hence, it provides a means to visually confirm that the addition of $\mathrm{CR}$ increases the air trapped in the concrete mixture, thereby increasing the number of voids in the concrete cylinders as mentioned above.

\section{Conclusions}

In this study, we investigated the properties of modified concrete with $\mathrm{CR}$ and the effect of the incorporation of HGM in the preparation of concrete. The mechanical and physical properties such as slump, density, compressive strength, and elasticity modulus of a specimen of concrete were studied. From the experimental results, the replacement of fine aggregates by HGM and CR induces a modification of the fresh and hardened properties of the prepared concrete samples. The sample with only HGM replacement possessed a compressive strength of 22.4 MPa. Moreover, the addition of HGM to the CR generates a synergistic effect that improves the compressive strength with HGM12.5-CR2.5 having the highest strength of 19.5 MPa. In addition, the slump was affected by the content of HGM, the slump was higher for samples with higher HGM content and density is greatly influenced by the higher rubber content. These effects are associated with the shape of the HGM and the least density of HGM and rubber, respectively. The results obtained were consistent with the change in the elasticity module of the prepared concrete samples, which was directly proportional to the increase in HGM content. From the SEM images, we were able to identify the presence of pores in the mixtures of concrete with higher CR content, thus the compressive strength is reduced. The XRD results show that the intensity of the peaks of the crystalline phases tends to increase when the percentage of HGM was higher, which means the quantity of those phases was found in most proportion of the mixture. Therefore, HGM plays a role in improving the interfacial adhesion between the cement matrix and aggregates. Hence, the introduction of HGM enhances compressive strength. The results obtained showed that 
the addition of HGM to CR modified the concrete, and it shows that this modified concrete may be employed for structural purposes as long as the percentage of $\mathrm{CR}$ is controlled within a reasonable range. It has the potential to be used as structural concrete. Additionally, the usage of $C R$ in concrete can reduce sand dredging, along with the reduction of $\mathrm{CR}$ waste going into landfill sites.

\section{Declaration of competing interest}

None declared under financial, profesional and personal competing interests.

\section{Acknowledgments}

The authors acknowledge Universidad Cooperativa de Colombia for financially supporting this work through the grant INV2219.

\section{References}

[1] V. Tam, M. Soomro, and A. C. Jorge, "A review of recycled aggregate in concrete applications (2000-2017)," Constr. Build. Mater, vol. 172, May 30 2018. [Online]. Available: https://doi.org/10.1016/j. conbuildmat.2018.03.240

[2] E. R. Teixeira and A. Camões and F. G. Branco, "Valorisation of wood fly ash on concrete," Resour. Conserv. Recycle., vol. 145, June 2019. [Online]. Available: https://doi.org/10.1016/j.resconrec.2019.02.028

[3] K. Hu, Y. Chen, F. Naz, C. Zeng, and S. Cao, "Separation studies of concrete and brick from construction and demolition waste," Resour. Conserv. Recycle., vol. 85, February 15 2019. [Online]. Available: https://doi.org/10.1016/j.wasman.2019.01.007

[4] T. Castaño, S. Linsel, A. Alujas, R. Orozco, and J. F. Martirena, "Influence of very fine fraction of mixed recycled aggregates on the mechanical properties and durability of mortars and concretes," Revista Facultad de Ingeniería Universidad de Antioquia, no. 81, September 2016. [Online]. Available: http://dx.doi.org/10.17533/ udea.redin.n81a08

[5] E. Pavón, I. Martínez, and M. Etxeberria, "The production of construction and demolition waste material and the use of recycled aggregates in Havana, Cuba," Revista Facultad de Ingeniería Universidad de Antioquia, no. 71, pp. 167-178, April 2014.

[6] L. F. Molina and M. F. Garzón, "Propiedades de concretos y morteros modificados con nanomateriales: Estado del arte," Arquetipo, no. 14, pp. 81-98, 2017.

[7] N. Camargo and C. Higuera, "Concreto hidraulico modificado con silice obtenida de la cascarilla de arroz," Cienc. e Ing. Neogranadina, vol. 27, no. 1, 2017. [Online]. Available: https: //doi.org/10.18359/rcin.1907

[8] P. Murthi, P. Awoyera, P. Selvara, D. Dharsana, and R. Gobinath, "Using silica mineral waste as aggregate in a green high strength concrete: Workability, strength, failure mode, and morphology assessment," Aust. J. Civ. Eng., vol. 16, no. 2, 2018. [Online]. Available: https://doi.org/10.1080/14488353.2018.1472539

[9] P. O. Awoyera, J. O. Akinmusuru, and J. M. Ndambuki, "Green concrete production with ceramic wastes and laterite," Constr. Build. Mater, vol. 117, August 1 2016. [Online]. Available: https: //doi.org/10.1016/j.conbuildmat.2016.04.108

[10] P. O. Awoyera, A. R. Dawson, N. H. Thom, and J. O. Akinmusuru, "Suitability of mortars produced using laterite and ceramic wastes: Mechanical and microscale analysis," Constr. Build. Mater., vol. 148,
September 1 2017. [Online]. Available: https://doi.org/10.1016/j. conbuildmat.2017.05.031

[11] T. Sathanandam, P. O. Awoyera, V. Vijayan, and K. Sathishkumar, "Low carbon building: Experimental insight on the use of fly ash and glass fiber for making geopolymer concrete," Sustain. Environ. Res., vol. 27, no. 3, May 2017. [Online]. Available: https://doi.org/10.1016/j.serj.2017.03.005

[12] T. Alexandru, B. Marinela, D. Laura, and B. Irina, "Mechanical and Environmental Performances of Concrete Using Recycled Materials," Procedia Manuf., vol. 32, 2019. [Online]. Available: https://doi.org/10.1016/j.promfg.2019.02.211

[13] K. Rashid, A. Yazdanbakhsh, and M. U. Rehman, "Sustainable selection of the concrete incorporating recycled tire aggregate to be used as medium to low strength material," J. Clean. Prod., vol. 224, July 1 2019. [Online]. Available: https://doi.org/10.1016/j.jclepro. 2019.03.197

[14] A. R. Khaloo, M. Dehestani, and P. Rahmatabadi, "Mechanical properties of concrete containing a high volume of tire-rubber particles," Waste Manag., vol. 28, no. 12, December 2008. [Online]. Available: https://doi.org/10.1016/j.wasman.2008.01.015

[15] H. A. Torres, "Valoración de propiedades mecánicas y de durabilidad de concreto adicionado con residuos de llantas de caucho," M.S. thesis, Escuela Colombiana de Ingeniería Julio Garavito, Bogotá, Colombia, 2014.

[16] S. Shahidan, E. Aminuddin, K. Mohd, N. I. Raihan, and N. A. Saiful, "Potential of hollow glass microsphere as cement replacement for lightweight foam concrete on thermal insulation performance," in International Symposium on Civil and Environmental Engineering 2016 (ISCEE 2016), Wuhan, China, 2017, p. 9.

[17] A. L. Brooks, H. Zhou, and D. Hanna, "Effects of different lightweight functional fillers for use in cementitious composites," Constr. Build. Mater., vol. 159, January 20 2018. [Online]. Available: https://doi.org/10.1016/j.conbuildmat.2017.10.102

[18] A. Hanif, Z. Lu, Y. Cheng, S. Diao, and Z. Li, "Effects of different lightweight functional fillers for use in cementitious composites," Int. J. Concr. Struct. Mater., vol. 11, no. 1, March 2017. [Online]. Available: https://doi.org/10.1007/s40069-016-0184-1

[19] Instituto Colombiano de Normas Técnicas y Certificación (ICONTEC), "Ingeniería civil y Arquitectura. Determinación de la masa unitaria y los vacíos entre partículas y agregados," Instituto Colombiano de Normas Técnicas y Certificación (ICONTEC), Bogotá, Col, Tech. Rep. NTC 92, 1995.

[20] Instituto Colombiano de Normas Técnicas y Certificación (ICONTEC), "Ingeniería civil y Arquitectura. Método para determinar la densidad y la absorción del agregado fino," Instituto Colombiano de Normas Técnicas y Certificación (ICONTEC), Bogotá, Col, Tech. Rep. NTC 237, 1995.

[21] Instituto Colombiano de Normas Técnicas y Certificación (ICONTEC), "Ingeniería civil y Arquitectura. Método de ensayo para determinar la densidad y la absorción del agregado grueso," Instituto Colombiano de Normas Técnicas y Certificación (ICONTEC), Bogotá, Col, Tech. Rep. NTC 176, 1995.

[22] Instituto Colombiano de Normas Técnicas y Certificación (ICONTEC), “Ingeniería civil y Arquitectura. Método de ensayo para el análisis por tamizado de los agregados finos y grueso," Instituto Colombiano de Normas Técnicas y Certificación (ICONTEC), Bogotá, Col, Tech. Rep. NTC 77, 2007.

[23] Standard Practice for Selecting Proportions for Normal, Heavyweight, and Mass Concrete (ACl 211.1-91), ACI Committee 211, 2002.

[24] Instituto Colombiano de Normas Técnicas y Certificación (ICONTEC), "Ingeniería civil y Arquitectura. Método de ensayo para determinar el asentamiento del concreto," Instituto Colombiano de Normas Técnicas y Certificación (ICONTEC), Bogotá, Col, Tech. Rep. NTC 396, 2018.

[25] Instituto Colombiano de Normas Técnicas y Certificación (ICONTEC), “Concretos. Elaboración y curado de especímenes de concreto en obra," Instituto Colombiano de Normas Técnicas y Certificación (ICONTEC), Bogotá, Col, Tech. Rep. NTC 550, 2000.

[26] H. Su, J. Yang, T. Ling, G. S. Ghataora, and S. Dirar, "Properties of concrete prepared with waste tyre rubber particles of uniform 
and varying sizes," J. Clean. Prod, vol. 91, March 15 2015. [Online]. Available: https://doi.org/10.1016/j.jclepro.2014.12.022

[27] A. Turatsinze and M. Garros, "On the modulus of elasticity and strain capacity of Self-Compacting Concrete incorporating rubber aggregates," J. Clean. Prod, vol. 52, no. 10, August 2008. [Online]. Available: https://doi.org/10.1016/j.resconrec.2008.06.012

[28] V. A. Perfilov, D. V. Oreshkin, and V. S. Semenov, "Environmentally Safe Mortar and Grouting Solutions with Hollow Glass Microspheres," Procedia Eng., vol. 150, 2016. [Online]. Available: https://doi.org/10.1016/j.proeng.2016.07.086
[29] L. Desgranges and et al, "Hydrogen thermal motion in calcium hydroxide: $\mathrm{Ca}(\mathrm{OH})_{2}, "$ Acta Crystallogr. Sect. B, vol. B49, 1993. [Online]. Available: https://doi.org/10.1107/S0108768193003556

[30] D. Oreshkin, V. Semenov, and T. Rozovskaya, "Properties of Light-weight Extruded Concrete with Hollow Glass Microspheres," Procedia Eng., vol. 153, 2016. [Online]. Available: https://doi.org/10. 1016/j.proeng.2016.08.214

[31] E. Zolotoyabko and et al, "Differences between bond lengths in biogenic and geological calcite," Cryst. Growth Des., vol. 10, no. 3, March 2010. [Online]. Available: https://doi.org/10.1021/cg901195t 